International Journal of Linguistics, Literature and Translation (IJLLT)

ISSN: 2617-0299 (Online); ISSN: 2708-0099 (Print)

DOI: $10.32996 / \mathrm{ijllt}$

Website: https://al-kindipublisher.com/index.php/ijllt

\title{
Lexemes and Semantic Relations in English and Arabic: A Contrastive Study
}

Amaal Kamal Al-Farra

A teacher of English and a lecturer at Al-Quds Open University, Gaza, Palestine

Corresponding Author: Amaal Kamal Al.Farra, E-mail: amaalkamal@hotmail.com

\section{ARTICLE INFORMATION}

Received: September 12, 2020

Accepted: October 10, 2020

Volume: 3

Issue: 10

DOI: 10.32996/ijllt.2020.3.10.4

\section{KEYWORDS}

Lexeme- homonym- synonymantonym- homophone- semanticcontrastive

\section{ABSTRACT}

Communicating via language is an important property of human beings. Usually one does not think of the relations between words. But from linguistic perspective, the words are not single units. They are linked to each other by semantic and formal relations. The focus of this paper is on different lexemes in English and Arabic. So, this research aims to investigate the major errors which EFL students encounter by the misuse of different lexemes. This is achieved through using the elicitation instrument by implementing two tests. A pretest and a posttest for the sixth-grade students. First the students face problems in dealing with homonyms, synonyms, antonyms and homophones as a result of negative interference between the two languages, Arabic and English. After extensive training the students get good results. They are able to overcome the ambiguity of these lexemes. This shows the importance of learning lexemes in both languages as this simplifies the communication and identifies the areas of ambiguity.

\section{Introduction}

Contrastive linguistics may roughly be defined as "a sub discipline of linguistics concerned with the comparison of two or more languages or subsystems of language" (as cited in Al-Ghamdi, 2016). It is used as a tool in this study focusing on the different use of homonyms, homographs, synonyms and antonyms in both languages, English and Arabic.

Generally, the sources of misunderstanding and lack of communication through language have been the focus of academic research. A major point in semantics is the study of ambiguity in human languages. So, the present study attempts to explore the difficulty and ambiguity in the use of different lexemes by giving definitions and examples for each lexeme in both languages, English and Arabic. After that, the researcher applies an empirical study to investigate the use of these different lexemes. A pretest/ posttest design will be used to see the effect of treatment on the same group of students.

\section{Literature Review}

\subsection{What is homonymy?}

It is known as different unrelated senses or meanings which are under same surface form of words (Ravin,Y.,\& Leacock, C., 2000). These words have identical spelling or orthographic forms but they are different in meaning. In general, it is expressed in two ways:

a. Homography in which the words are identical in spelling but they are different in meaning.

b. Homophony in which the words are different in spelling but they are similar in pronunciation.

As for homonym, it is a word that is spelt like another word or pronounced like it but which has a different meaning. In strict sense, homonyms have same spelling, same pronunciation and different meaning e.g. the word "fare" means a passenger and the word "fare" means a price. Also, the word "trunk" means a large strong box and it has another meaning "the main stem of a tree". In wider sense, homonym can include words that have the same pronunciation but different spelling and they are called homophones. Examples:

a. ad(advertisement), add "to include"

K C AL-KINDI CENTER

R D FOR RESEARCH AND $\mathbf{R} \mathbf{D}$ DEVELOPMENT Your gateway to world-class research
Published by Al-KindiCenter for Research and Development. Copyright (c) the author(s). This is an open access article under CC BY license (https://creativecommons.org/licenses/by/4.0/) 
b. to, too, two

Or they can have same spelling but different pronunciation and called homographs:

a. bow /bou/ a weapon used for shooting arrows

b. bow /bau/ to move your head forwards and downwards.

Homophones are also called heterophones (Joshi, 2014).

\subsubsection{Types of Homonymy}

Baron (2005) states that homonymy can be divided in absolute and in partial homonymy:

A. Absolute homonyms: They are unrelated in meaning. All their forms are identical in pronunciation and spelling. Some identical forms are grammatical equivalent in which they belong to the same word-class. They have the same syntactic function and occur in the same grammatical environment e.g.

1. mail ( noun "posted letters and parcels")

2. mail ( noun "armour made of rings or chains) (Baron, 2005).

B. Partial Homonyms: They fail to fulfill one or more features of absolute homonymy. They could have a lack in spelling, pronunciation, form or grammatical equivalence e.g.

1. Visit ( verb "to see a person or a place for a short time")

2. Visit ( noun " a period of time when sb goes to see a person or a place") (Baron, 2005).

\subsubsection{Homonymy and Polysemy}

The morpheme has form and meaning. It is easy to determine the form but difficult to determine the meaning. In homonyms, e.g. bank "a financial institution" and bank "the edge of a stream", the pronunciation and spelling are identical but the meanings are unrelated. But the words "stake" and "steak" are identical in pronunciation but different in spelling. There are also homographs which are identical in spelling bur different in meaning; for example, "bow" which rhymes with "go", means an instrument for shooting arrows. But "bow" rhyming with "cow", denotes a bending of the upper body as a form of respectful greeting. This creates ambiguity and lexicographers sometimes have to decide whether a form with different meanings is a kind of polysemy or homonymy. Generally, dictionaries differentiate between them by making the polysemous item a single dictionary entry. On the other hand, they make two or more homophonous lexemes separate entries. Thus, the word "bank" has two entries but the word "head" has a single entry where it has several related meanings when we speak of the head of person, the head of company, the head of lettuce or cabbage. This is done on the bases of etymology and the semantic relatedness. (Kreidler, 2013, p. 36).

\subsubsection{Homonymy, polysemy and ambiguity}

Semantic ambiguity refers to the differences in meaning and it is related to homonymy or polysemy, depending on whether or not the meanings are related. An example of homonymy is the "bark" of the dog versus the "bark" of a tree. Whereas "opening" a door versus "opening" a book is an example of polysemy.

Also, there is a syntactic ambiguity refers to differences in syntactic category (e.g. play can occur as either a noun or a verb). (Robert Krovetz, W. \& Bruce Croft, 1992) state that syntactic and semantic ambiguity are orthogonal, since a word can have related meanings in different categories (He will review the review when he gets back from vacation), or unrelated meanings in different categories (Can you see the can?). Despite the theoretical distinction between homonymy and polysemy, still it is not easy to differentiate between them in practice.

\subsection{Homophones}

Hobbs (2006) defines the homophone in his compiled dictionary as, "a word that is pronounced the same as another (a "sound-alike" or an aural/oral echo) but which differs in spelling and meaning, such as "cite, sight and site."

So, homophones are words that have identical pronunciation but with different spellings, semantic meanings and different forms (Amir, 2010). Misusing homophones is common amongst English speaking native and non-native speakers. Connors, R.J.\& Lunsford, A.A. (1988) state that the misuse of homophones such as "there, their, they're" in writing is one of the most 
common formal errors in English writing of American college students. This causes comprehension problems. It is very important for learners to distinguish between different homophonous spellings and their associated meanings.

\subsubsection{The conflict of homophones}

It has been seen that English has homophones more than many other languages for several reasons as stated in the dictionary of homophones and homographs (Hobbs, 2006, p. 5). These reasons are:

a. English has borrowed from other languages such as "air. Err and heir" which stem from Middle English, Old French and Latin.

b. English has shortening words which have homophones e.g. "plane" (from airplane) is homophonous with "plain". Also the shortening "ads" (from advertisement) is homophonous with "adds" and adz(e).

c. Homophones are created by converting a proper name into specific things e.g. "James (Joule)" is homophonous with "jewel".

d. Sometimes the acronyms create homophonous words such as WAACS (Women's Army Auxiliary Crops) is homophonic with "whacks" and "wax"

e. The process of assimilation by which " $d$ " in "chased" is pronounced " $t$ " as in "chaste" for example: "The seriously chased are seldom chaste for long." Or its reversal; "The seriously chaste are seldom chased for long."

So many linguists discuss if homophones, whether in English or in any other language, lead to self- destruct because of the confusion and ambiguity they create. One of them is Jules Gillieron in his doctrine (1902-1921) who states that two words of different origin which become homophonous by regular sound- changes may have ambiguity interference with each other. He calls this a "conflict of homophones". Moreover, homophones are considered partial homonyms. They are illustrated from the pairs (threw/ through) and (rode/rowed). As a result of the ambiguity of these pairs, homonymic clash or conflict is said to have occurred (Crystal, 2003).

\subsubsection{Heteronyms}

Heteronyms are words that have two different possible pronunciations that are associated with two (or more) different meanings. Maryanne Martin, Gregory V. Jones, Douglas L. Nelson \& Louise Nelson (1981) suggest that two types of heteronyms may usefully be distinguished; "strong" and "weak". Strong heteronyms can be seen in the following example which is cited before as being homographs:

a. bow /bou/ a weapon used for shooting arrows

b. bow /bau/ to move your head forwards and downwards.

c.

On the other hand, the weak heteronyms are words whose different phonemic representations are associated with meanings that although different, are not related. Rather, the different meanings derive from the same lexical entry (e.g. read is pronounced/ri:d/ and/red/ in the present and past tenses, respectively).

\subsubsection{Hyponymy}

In linguistics, a hyponym is originated from (Greek hupó, "under" and ónoma, "name"). It is a word or phrase whose semantic field is included within that of another word, its hyperonym or hypernym (from Greek hupér, "over" andónoma, "name"). The hyponym shares a type-of relationship with its hypernym. For example, pigeon, crow, eagle and seagull are all hyponyms of bird (their hypernym); which, in turn, is a hyponym of animal.

(https://en.wikipedia.org/wiki/Hyponymy_and_hypernymy, 2016)

To shed the light on this topic, Professor Amer (2014) explains a kind of relationship called the "entailment". He state the following examples:

a. There are tulips in the vase.

b. There are flowers in the vase.

c.

There is an analogous relationship between these two examples. If we know that the first sentence is true, then the second one is also true; but if we know that the first sentence is not true, we cannot say anything about the truth of the second one. The term tulip is a hyponym of flower. The word flower is the superordinate of tulip. Moreover, he states that any lexeme that can be substituted for a hyponym is also a hyponym. So, daffodil and rose are two co-hyponyms of tulip. 


\subsection{Synonymy}

Partington (1998) defines synonymy as the words that have the same sense but not the same reference. There are different kinds of synonymy. (Lyons, 1981) distinguishes between two kinds of synonymy. The first is the complete synonymy if in certain contexts, they have the same descriptive, expressive and social meanings. The second kind is the absolute synonymy if they have the same distribution and are completely synonymous in all their meanings and in all their contexts of occurrence and semantic equivalence. Synonyms can be substituted for each other without affecting the truth value of the sentence.

* Youth/adolescent $\quad *$ postpone $=$ put off $\quad *$ vomit $=$ throw up

* couch = sofa $\quad *$ Automobile/car $\quad *$ Remember $/$ recall

* Purchase/buy

Synonyms can be any part of speech (such as nouns, verbs, adjectives, adverbs or prepositions), as long as both words belong to the same part of speech. Examples:

Verb: buy and purchase

Adjective: big and large

Adverb: quickly and speedily

Preposition: on and upon

\subsubsection{Synonyms and ambiguity}

Synonyms are defined with respect to certain senses of words; for instance, pupil as the aperture in the iris of the eye is not synonymous with student. Such like, he expired means the same as he died, yet my passport has expired cannot be replaced by my passport has died. The same problems are also created with the following examples:

! $\mathrm{A}$ big house $=\mathrm{A}$ large house

! A big sister \pm A large sister

(Pustejovsky, 2005)

\subsection{Antonymy}

Antonymy is oppositeness of meaning between a word and the other word or among words in the same part of speech, such as good-bad (adjective-adjective) and fast-slowly (adverb-adverb). Antonymy covers the relation between lexical items whose meanings stand in opposition to each other and it is often thought as the opposite of synonymy.

There are three main types of antonymy, that is, gradable antonymy, complementary antonymy, and converse antonymy (Hu, 2001):

a. Gradable antonymy is the commonest type of antonymy. The antonym pairs like hot/cold, big/small and tall/short all belong to the gradable antonyms. They are mainly adjectives.

b. Complementary antonymy like the antonyms wake/asleep, married/single, pass/fail, alive/dead and male/female.

c. Converse antonymy like the pairs husband/wife, doctor/patient, teacher/student, buy/sell, above/below and employer/employee. They show a reversal relationship. A is B's husband means B is A's wife. A is B's doctor means $B$ is $A^{\prime}$ s patient. A is B's teacher means B is A's student. It is also known as relational opposites.

\subsection{Homonymy in Arabic}

Abdul-Raof (2000) defines homonymy in Arabic as the words that have the same phonological form but different meanings as in:

\begin{tabular}{|c|c|}
\hline Arabic Word & The same phonological form but different meanings \\
\hline أ) ساعة & $\begin{array}{ll}\text { 1. } & \text { Time: It is ten o'clock. (الساعة العانشرة) } \\
\text { 2. } & \text { Watch: I have a digital watch. (عندي ساعة رقمية) }\end{array}$ \\
\hline 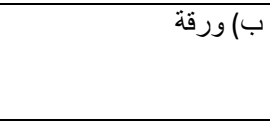 & 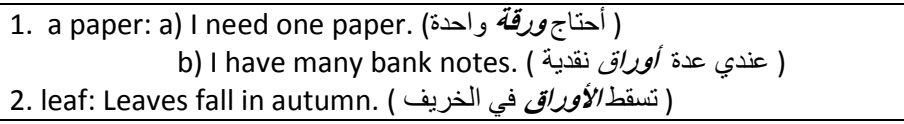 \\
\hline ج) دقيق & $\begin{array}{l}\text { 1. accurate: His work is accurate. (عمله دقيق ) } \\
\text { 2. flour: I need to buy flour. (أحتاج أن أشتري دقيق) }\end{array}$ \\
\hline
\end{tabular}




\subsection{Polysemous words: ( المفردات متعددة المعنى)}

"A polyseme is a word which has several meanings" (Abdul-Raof, 2000). Some examples of polysemes are:

\begin{tabular}{|c|c|}
\hline The Arabic Word & Its Several Meanings \\
\hline أ)سائل & $\begin{array}{l}\text { 1. The one who asks (a question or when is in need. I shall answer the one } \\
\text { who asks and help him. (هأجيب السائل على سؤ اله وأساعد؟ ) (هل العصبر سائل) } \\
\text { 2. liquid: Is the juice a liquid? }\end{array}$ \\
\hline ب) اظرف & $\begin{array}{l}\text { 1. envelope: I put some money in an envelope. (وضعت بعض النقود في الظرف) } \\
\text { 2. circumstances: I have had difficult circumstances that prevented me from } \\
\text { travelling. ( لابي ظروف قاهرة منعتني من السفر) }\end{array}$ \\
\hline
\end{tabular}

\subsection{Synonyms}

Abdul-Raof (2000) states that the words which signify the same meanings are synonyms. But he adds that synonymy does not mean identical meaning between two words but the two words can be used in different contexts with a similar meaning. Some examples of the Arabic synonyms are:

\begin{tabular}{|c|c|c|}
\hline ينسحب & To withdraw/ to retreat & بتقهقر = ينر اجع = \\
\hline | يبني & To build/ to construct & يشيد= يعمر= \\
\hline يعلم & To teach & يلقن= يدرس= يفهم= يغذي بأفكار \\
\hline بعطي & To give & إيب= ينفق= يمنح \\
\hline مجتهد & Hard working & حريص= مشغول= مو اضب= ملتزم \\
\hline 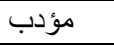 & Polite/ respectful of others & ذو حياء= مطيع= خلوق= محترم \\
\hline 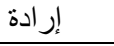 & Will/ determination & عزيمة= تصميم \\
\hline مضطهد & Oppressed & مظلوم \\
\hline
\end{tabular}

\subsection{Antonyms}

Moreover, Abdul- Raof (2000:50) states some examples of the antonyms in Arabic. He defines them as words which have opposite meanings to other words such as:

\begin{tabular}{|c|c|}
\hline educated/ learned & uneducated/ illiterate جاهل/ أمي/ غير متعلم \\
\hline clever & $\begin{array}{ll}\text { غبي } & \text { stupid } \\
\end{array}$ \\
\hline virtue & إنيلة \\
\hline married $(\mathrm{m})$ & single $(m)$ \\
\hline married $(F)$ & single (f) \\
\hline man & woman \\
\hline truthful & 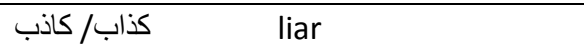 \\
\hline 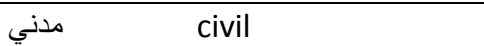 & عري \\
\hline happy & حزين \\
\hline poor & rich \\
\hline beautiful/ handsome وسيم/ جميل & ugly \\
\hline conservative & liberal \\
\hline hot & cold \\
\hline truth & falsehood \\
\hline peace & war \\
\hline friend & enemy \\
\hline order & chaos \\
\hline
\end{tabular}




\subsection{Homonymy and Ambiguity in Arabic:}

There are two sorts of ambiguity in Arabic; lexical and syntactic. The lexical ambiguity occurs when the sentence contains a word which has more than one meaning as the following examples which are stated by (Amir, 2010).

إن الأمر لجلبل

a. The matter is big.

b. The matter is trivial.

The reason of this ambiguity is that the two sentences contain homonyms that have antonymous meanings.

The syntactic ambiguity is related to the grammatical construction of the sentence. For example:

مساعدة الو الدين

a. Help that is given from parents.

b. Help that is given to parents.

To sum up, in English the word homonymy is divided into homophony and homography but in Arabic this term is translated as المشترك اللفظي and they have the same definitions in both languages.

\section{Research Question}

What are the major errors that EFL students may commit in using antonyms, synonyms, homonyms and homographs?

\section{Methodology}

\subsection{Participants}

The participants are 40 female students from sixth grade. They are from an UNRWA school. They learn English as a foreign language.

\subsection{Data Collection}

An elicitation instrument is used to examine the participants' understanding of the usage of, "Synonyms, Antonyms, Homonyms and Homographs." Some of the questions are adapted from English for everyone (2012). The elicitation instrument is in the Appendix.

\subsection{Procedures}

An informed consent to participate in the research is signed from the school principal. Then, the pre-test is given to the students. It is checked and their marks are scored. Those students got an extensive training by giving different activities on the four main topics, "Synonyms, Antonyms, Homonyms and Homographs." After that the same elicitation instrument is given again to this control group of students. Results are recorded to be analyzed and to be compared with the results of the pre-test.

\subsection{Data Analysis}

The students' answers of both pre-test and post-test were checked. The percentage is calculated for each correct and incorrect answer of both tests.

\section{Findings and Discussion}

\subsection{Pre-Test Results of $\mathbf{4 0}$ students}

Question $(A)$ :

\begin{tabular}{|l|l|l|l|l|}
\hline $\begin{array}{l}\text { No. of } \\
\text { Ques. }\end{array}$ & $\begin{array}{l}\text { No. of Correct } \\
\text { Answers }\end{array}$ & $\begin{array}{l}\text { Percentage of } \\
\text { correct answers }\end{array}$ & $\begin{array}{l}\text { No. of incorrect } \\
\text { Answers }\end{array}$ & $\begin{array}{l}\text { Percentage of } \\
\text { incorrect answers }\end{array}$ \\
\hline 1. & 37 & $92.5 \%$ & 3 & $7.5 \%$ \\
\hline 2. & 31 & $77.5 \%$ & 9 & $22.5 \%$ \\
\hline 3. & 9 & $22.5 \%$ & 31 & $77.5 \%$ \\
\hline 4. & 11 & $27.5 \%$ & 29 & $72.5 \%$ \\
\hline 5. & 33 & $82.5 \%$ & 7 & $17.5 \%$ \\
\hline 6. & 27 & $67.5 \%$ & 13 & $32.5 \%$ \\
\hline Total & 148 & $61.6 \%$ & 92 & $38.33 \%$ \\
\hline
\end{tabular}

There are 148 correct answers and 92 incorrect answers. 
Question (B):

\begin{tabular}{|l|l|l|l|l|}
\hline $\begin{array}{l}\text { No. of } \\
\text { Ques. }\end{array}$ & $\begin{array}{l}\text { No. of Correct } \\
\text { Answers }\end{array}$ & $\begin{array}{l}\text { Percentage of } \\
\text { correct answers }\end{array}$ & $\begin{array}{l}\text { No. of incorrect } \\
\text { Answers }\end{array}$ & $\begin{array}{l}\text { Percentage of } \\
\text { incorrect answers }\end{array}$ \\
\hline 1. & 11 & $27.5 \%$ & 29 & $72.5 \%$ \\
\hline 2. & 12 & $30 \%$ & 28 & $70 \%$ \\
\hline 3. & 18 & $45 \%$ & 22 & $55 \%$ \\
\hline 4. & 12 & $30 \%$ & 28 & $70 \%$ \\
\hline 5. & 17 & $42.5 \%$ & 23 & $57.5 \%$ \\
\hline 6. & 9 & $22.5 \%$ & 31 & $77.5 \%$ \\
\hline Total & 79 & $32.9 \%$ & 161 & $67 \%$ \\
\hline
\end{tabular}

There are 79 correct answers and 161 incorrect answers.

Question (C):

\begin{tabular}{|l|l|l|l|l|}
\hline $\begin{array}{l}\text { No. of } \\
\text { Ques. }\end{array}$ & $\begin{array}{l}\text { No. of Correct } \\
\text { Answers }\end{array}$ & $\begin{array}{l}\text { Percentage of } \\
\text { correct answers }\end{array}$ & $\begin{array}{l}\text { No. of incorrect } \\
\text { Answers }\end{array}$ & $\begin{array}{l}\text { Percentage of } \\
\text { incorrect answers }\end{array}$ \\
\hline 1. & 36 & $90 \%$ & 4 & $10 \%$ \\
\hline 2. & 38 & $95 \%$ & 2 & $5 \%$ \\
\hline 3. & 34 & $85 \%$ & 6 & $15 \%$ \\
\hline 4. & 34 & $85 \%$ & 6 & $15 \%$ \\
\hline 5. & 22 & $55 \%$ & 18 & $45 \%$ \\
\hline 6. & 20 & $50 \%$ & 20 & $50 \%$ \\
\hline Total & 184 & $76.6 \%$ & 56 & $23.3 \%$ \\
\hline
\end{tabular}

There are 184 correct answers and 56 incorrect answers.

Question (D):

\begin{tabular}{|l|l|l|l|l|}
\hline $\begin{array}{l}\text { No. of } \\
\text { Ques. }\end{array}$ & $\begin{array}{l}\text { No. of Correct } \\
\text { Answers }\end{array}$ & $\begin{array}{l}\text { Percentage of } \\
\text { correct answers }\end{array}$ & $\begin{array}{l}\text { No. of incorrect } \\
\text { Answers }\end{array}$ & $\begin{array}{l}\text { Percentage of } \\
\text { incorrect answers }\end{array}$ \\
\hline 1. & 21 & $52.5 \%$ & 19 & 47.5 \\
\hline 2. & 10 & $25 \%$ & 30 & 75 \\
\hline 3. & 19 & $47.5 \%$ & 21 & 52.5 \\
\hline 4. & 12 & $30 \%$ & 28 & 70 \\
\hline 5. & 27 & $67.5 \%$ & 13 & 32.5 \\
\hline 6. & 30 & $75 \%$ & 10 & 25 \\
\hline Total & 119 & $49.58 \%$ & 121 & 50.4 \\
\hline
\end{tabular}

There are 119 correct answers and 121 incorrect answers.

\subsection{Post- Test results for the same students}

Question (A):

\begin{tabular}{|l|l|l|l|l|}
\hline $\begin{array}{l}\text { No. of } \\
\text { Ques. }\end{array}$ & $\begin{array}{l}\text { No. of Correct } \\
\text { Answers }\end{array}$ & $\begin{array}{l}\text { Percentage of } \\
\text { correct answers }\end{array}$ & $\begin{array}{l}\text { No. of incorrect } \\
\text { Answers }\end{array}$ & $\begin{array}{l}\text { Percentage of } \\
\text { incorrect answers }\end{array}$ \\
\hline 1. & 39 & $97.5 \%$ & 1 & $2.5 \%$ \\
\hline 2. & 40 & $100 \%$ & - & $-\%$ \\
\hline 3. & 36 & $90 \%$ & 4 & $10 \%$ \\
\hline 4. & 32 & $80 \%$ & 8 & $20 \%$ \\
\hline 5. & 39 & $97.5 \%$ & 1 & $2.5 \%$ \\
\hline 6. & 35 & $87.5 \%$ & 5 & $12.5 \%$ \\
\hline Total & 221 & $92 \%$ & 19 & $7.9 \%$ \\
\hline
\end{tabular}

There are 221 correct answers and 19 incorrect answers.

Question (B):

\begin{tabular}{|l|l|l|l|l|}
\hline $\begin{array}{l}\text { No. of } \\
\text { Ques. }\end{array}$ & $\begin{array}{l}\text { No. of Correct } \\
\text { Answers }\end{array}$ & $\begin{array}{l}\text { Percentage of } \\
\text { correct answers }\end{array}$ & $\begin{array}{l}\text { No. of incorrect } \\
\text { Answers }\end{array}$ & $\begin{array}{l}\text { Percentage of } \\
\text { incorrect answers }\end{array}$ \\
\hline 1. & 35 & $87.5 \%$ & 5 & $12.5 \%$ \\
\hline 2. & 32 & $80 \%$ & 8 & $20 \%$ \\
\hline
\end{tabular}




\begin{tabular}{|l|l|l|l|l|}
\hline 3. & 33 & $82.5 \%$ & 7 & $17.5 \%$ \\
\hline 4. & 34 & $85 \%$ & 6 & $15 \%$ \\
\hline 5. & 28 & $70 \%$ & 12 & $30 \%$ \\
\hline 6. & 33 & $82.5 \%$ & 7 & $17.5 \%$ \\
\hline Total & 195 & $81.25 \%$ & 45 & $18.75 \%$ \\
\hline
\end{tabular}

There are 195 correct answers and 45 incorrect answers.

Question (C):

\begin{tabular}{|l|l|l|l|l|}
\hline $\begin{array}{l}\text { No. of } \\
\text { Ques. }\end{array}$ & $\begin{array}{l}\text { No. of Correct } \\
\text { Answers }\end{array}$ & $\begin{array}{l}\text { Percentage of } \\
\text { correct answers }\end{array}$ & $\begin{array}{l}\text { No. of incorrect } \\
\text { Answers }\end{array}$ & $\begin{array}{l}\text { Percentage of } \\
\text { incorrect answers }\end{array}$ \\
\hline 1. & 31 & $77.5 \%$ & 9 & $22.5 \%$ \\
\hline 2. & 32 & $80 \%$ & 8 & $20 \%$ \\
\hline 3. & 35 & $87.5 \%$ & 5 & $12.5 \%$ \\
\hline 4. & 35 & $87.5 \%$ & 5 & $12.5 \%$ \\
\hline 5. & 40 & $100 \%$ & - & - \\
\hline 6. & 40 & $100 \%$ & - & - \\
\hline Total & 213 & $88.75 \%$ & 27 & $11.25 \%$ \\
\hline
\end{tabular}

There are 213 correct answers and 27 incorrect answers.

Question (D):

\begin{tabular}{|l|l|l|l|l|}
\hline $\begin{array}{l}\text { No. of } \\
\text { Ques. }\end{array}$ & $\begin{array}{l}\text { No. of Correct } \\
\text { Answers }\end{array}$ & $\begin{array}{l}\text { Percentage of } \\
\text { correct answers }\end{array}$ & $\begin{array}{l}\text { No. of incorrect } \\
\text { Answers }\end{array}$ & $\begin{array}{l}\text { Percentage of } \\
\text { incorrect answers }\end{array}$ \\
\hline 1. & 38 & $95 \%$ & 2 & $5 \%$ \\
\hline 2. & 31 & $77.5 \%$ & 9 & $22.5 \%$ \\
\hline 3. & 38 & $95 \%$ & 2 & $5 \%$ \\
\hline 4. & 34 & $85 \%$ & 6 & $15 \%$ \\
\hline 5. & 34 & $85 \%$ & 6 & $15 \%$ \\
\hline 6. & 38 & $95 \%$ & 2 & $5 \%$ \\
\hline Total & 213 & $88.75 \%$ & 27 & $11.25 \%$ \\
\hline
\end{tabular}

There are 213 correct answers and 27 incorrect answers.

A Comparison between the results of the two tests:

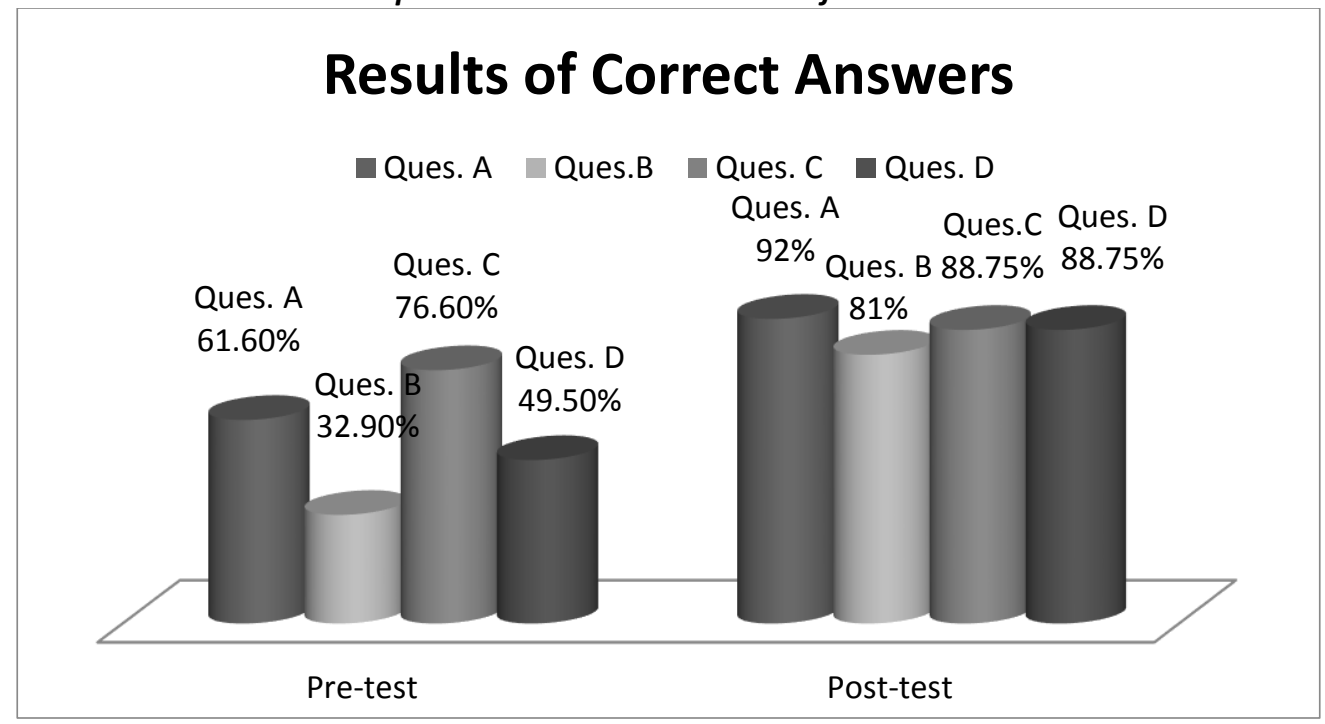

As seen from the tables of pre-test, the students face difficulties mostly in the second question which is about the use of synonyms and in the fourth question which is about the use of homophones. This is due to the conflict and ambiguity of the use of these two topics. Moreover, the negative interference of mother tongue language plays a crucial role in this ambiguity. But indeed, the teacher could solve this problem by giving extra activities and more exercises to cover the four areas of ambiguity, the antonyms, synonym, homonyms and homophones. 
Regarding the results of the post-test, the students did a good job and had higher marks in the four topics of the test due to the extensive training.

\section{Conclusion}

This study is intended to seek answers for the research central question which focuses on the major errors that EFL students may commit in using antonyms, synonyms, homonyms and homographs. It helps the reader find the similarities and differences between Arabic and English languages through the contrastive analysis of these lexemes. As it is seen, there are syntactic and semantic ambiguity and they are orthogonal, since a word can have related meanings in different categories or unrelated meanings in different categories. Despite the theoretical distinction between homonymy and polysemy, still it is not easy to differentiate between them in practice and that is found in the other aspects of lexemes.

However, the findings of this study show that the conflict and ambiguity among students are found in two topics: the synonyms and the homophones. Therefore, teachers should pay attention for the intralanguage interference as mother tongue has negative interference in dealing with the different lexemes of foreign language. But with extra practice, students will be able to overcome the ambiguity of different lexemes and will use the English words more efficiently as seen in the results of the post-test.

Still, this study did not focus on all types of lexemes. Other types such as grammatical categories, idioms, phrasal verbs, derivations and inflections in morphology need to be focused upon in both languages (Arabic and English) in future work.

\section{Recommendations}

\subsection{To the Teachers}

The teachers should differentiate between errors and mistakes. When the students make errors, that means they do not know the answer and they need more explanations and training from their teachers. On the other hand, the mistake is just a slip of the tongue and it can be self- corrected. So, students should not by frustrated by the errors they commit. Error leads to good learning. Jacobson, Lapp and Flood (2006) suggest seven steps for teaching these different lexemes as follows:

a. Reading or listening to a text which contains different antonyms, synonyms, homonyms and homophones. Then asking students to underline them.

b. Visualizing the meaning: Ask students to define each word by giving its meaning in Arabic, then using it in a meaningful sentence.

c. Identifying the grammatical structure: After reading the text, ask students to underline the target words, then to tell you the part of speech for each word whether it is verb, adjective, adverb or noun.

d. Categorizing words: Let students practice drawing a chart having a drawn house for nouns, an explosive symbol to represent nouns and a happy face to represent adjectives. Then students can categorize the different lexemes under the appropriate symbol indicating the correct part of speech.

e. Analyzing word meanings within context: Prepare and read aloud cloze sentences that have a space for the appropriate homonym, antonym or synonym. Write the missing word on coloured construction paper and post it on the board. Students can choose the suitable one. Discuss the Arabic meaning of each missing word.

f. Owing the words: Prepare a list of the words that you like to review with the class. Ask each group of students to draw a sketch which represents a pair of words homonyms, antonyms or synonyms. Call the words and the students who have their sketch, can present their work using them in meaningful sentences.

g. Extending and evaluating new meanings: As an additional review task, you can prepare 10 to 20 cards with words written on both sides on one of previous topics. They could be antonyms, homonyms, homographs, homophones or synonyms. Provide the students, in groups, with typed sentences. Students choose the suitable side of word card and write it.

\subsection{To the Supervisors}

Lots of training courses should be done from time to time to the teachers to assure the active learning and the effective ways of teaching different lexemes. 


\section{References}

[1] Abdul-Raof, H. (2000). Arabic Stylistics: A Coursebook. Michigan: Harrassowitz.

[2] Amer, W. M. (2014). Issues in Semantics. Gaza: The Islamic University.

[3] Amir, A. A. (2010). Homonymy in English and Arabic: A contrastive study. University of Babylon.

[4] Baron, K. (2005). Lexical Relations: Homonymy.

[5] Connors, R.J.\& Lunsford, A.A. (1988). Frequency of formal errors in current college writing, or Ma ams Pa Kettle do research (Vol. 39). College Composition and Communication.

[6] Crystal, D. (2003). A Dictionary of Linguistics and Phonetics (5th ed.). Oxford: lackwell Publishers Ltd.

[7] English for everyone. (2012). Retrieved from http://www.englishforeveryone.org/.

[8] Hobbs, J. (2006). Homophones and Homographs: An American Dictionary (4th ed.). McFarland\& Company.

[9] https://en.wikipedia.org/wiki/Hyponymy_and_hypernymy. (2016, March 27). Retrieved from Wikipedia The free encyclopedia.

[10] Hu, Z. L. (2001). Linguistics. A Coursebook. Beijing: Beijing University Press.

[11] Jacobson, J., Lapp, D. and Flood, J. (2007), A Seven-Step Instructional Plan for Teaching English-Language Learners to Comprehend and Use Homonyms, Homophones, and Homographs. Journal of Adolescent \& Adult Literacy, 51: 98-111. doi: 10.1598/JAAL.51.2.2

[12] Joshi, M. (2014). Homonyms, Homophones and Homographs: Vocabulary Building (Vol. 3). Manik Joshi.

[13] Kreidler, C. W. (2013). Introducing English Semantics.

[14] Lyons, J. (1981). Language and Linguistics Cambridge textbooks in linguistics. Cambridge University Press.

[15] Maryanne Martin, Gregory V. Jones, Douglas L. Nelson and Louise Nelson. (1981). METHODS \& DESIGNS Heteronyms and polyphones: Categories of words with multiple phonemic representations, 13 (3). Florida: University of South Florida.

[16] Ali, M. (2011). Elim Al Dalalah: Eli Al Mana. Amman: Dar Al-Falah

[17] Partington, A. (1998). Patterns and Meanings: Using Corpora for English Language Research and Teaching (Vol. 2). John Benjamins Publishing.

[18] Pustejovsky, J. (2005). Word Meaning. Washington.

[19] Ravin,Y.,\& Leacock, C. (2000). Polysemy: Theoretical and Computational Approaches: Theoretical and Computational Approaches. Oxford: OUP.

[20] Robert Krovetz, W. Bruce Croft. (1992). Lexical ambiguity and information retrieval (Vol. 10). New York: Journal ACM Transactions on Information Systems (TOIS). doi:10.1145/146802.146810 


\section{Appendix}

\section{Sixth Grade Pretest}

\section{Usage of Antonyms}

A) Choose the word that is most opposite in meaning to the boldface word:

\begin{tabular}{|ll|lll|}
\hline 1. Up & a) down & b) above & c) inside \\
\hline 2. Give & a) share & b) take & c) release \\
\hline 3. & Unhappy & a) glad & b) sad & c)calm \\
\hline 4. Buy & a) sell & b) have & c) hold \\
\hline 5. Slow & a) dark & b) fast & c) lucky & \\
\hline 6. Safe & b) dangerous & b) important & c) terrible
\end{tabular}

\section{Usage of Synonyms}

B) Choose the best synonym for the following words:

\begin{tabular}{|c|c|c|c|c|c|}
\hline 1. & Kind & a) & nice & b) wild & c) funny \\
\hline 2. & Fast & a) & clean & b) main & c) quick \\
\hline 3. & Glad & a) & broken & b) happy & c) open \\
\hline 4. & Noisy & a) & first & b) loud & c) low \\
\hline 5. & scared & a) & sad & b) angry & c) afraid \\
\hline & cheap & a) & valuable & b) inexp & (e c) costly \\
\hline
\end{tabular}

\section{Usage of Homonyms}

C) Choose (a) or (b):

1. The children are going to watch ( ) TV tonight. - What time is it? I don't have my watch ( ).

2. Let's play ( ) basketball. - The author wrote a play. ( )

3. My rabbits are in the pen ( ) Please, write with a black pen. ( )

a) A small clock which you wear.

b) Look at.

a) Share in sport.

b) Something to act.

a) A writing instrument which uses ink.

b) A closed place.

\section{Usage of Homophones}

D) Choose the correct word:

1. Can I go to the party (to - too - two).

2. This is my favourite (pare - pair - pear) of jeans.

3. The children got (bored - board) in the class.

4. The students carried (there - they're - their) bags.

5. Ben is going to (wear - ware) his new shirt today.

6. Is it going to (rein - rain - reign) this evening? 